

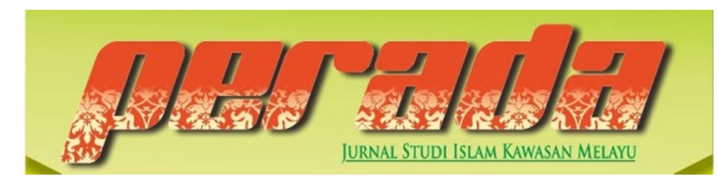

Perada: Jurnal Studi Islam Kawasan Melayu

ISSN 2656-7202 (P) ISSN 2655-6626 (0)

Volume 3 Nomor 1, Januari-Juni 2020

DOI: https://doi.org/10.35961/perada.v3i1.132

\title{
KISAH DALAM AL-QUR'AN \\ (STUDI KITAB MADKHAL ILA AL-QURAN AL KARIM KARYA MOHAMMED ABED AL-JABIRI)
}

\author{
Edi Hermanto \\ Universitas Islam Negeri Sultan Syarif Kasim Riau \\ edi.hermanto@uin-suska.ac.id \\ Nurfajriyani \\ Institut Agama Islam Negeri Ambon \\ nurfajriyani@iainambon.ac.id \\ Afriadi Putra \\ Universitas Islam Negeri Sultan Syarif Kasim Riau \\ afriadi.putra@uin-suska.ac.id \\ Ali Akbar \\ Universitas Islam Negeri Sultan Syarif Kasim Riau \\ aliakbarusman@yahoo.co.id
}

\begin{abstract}
ABSTRAK
Tulisan ini membahas tentang kisah dalam Al-Qur'an pada kitab madkhal ila Al-Qur'an al-Karim karya M. Abed al-Jabiri. Kajian ini penting untuk melihat konsep kisah Al-Qur'an sebagai salah satu pisau analisis untuk menafsirkan Al-Qur'an. Disamping itu, dalam tafsirnya ini M. Abed alJabiri memiliki gagasan besar tentang pengembangan ulumul qur'an yang menurutnya selama ini hanya berjalan di tempat, sehingga diperlukan analisis baru untuk menangkap pesan-pesan yang ingin disampaikan Al-Qur'an. Di dalam kitab ini langkah awal yang dilakukan al-Jabiri adalah merekonstruksi makna Al-Qur'an, al-Jabiri memberikan kritik atas berbagai definisi yang telah dikonstruksi oleh para ulama klasik seperti al-Suyuti, al-Syanqiti, al-Isfahani dan lain sebagainya. Selanjutnya, al-Jabiri mengklasifikasi surat-surat Al-Qur'an yang berbicara tentang kisah dalam kategori makiyyah dan madaniyyah. Kategori makiyyah, dibagi dalam dua tahap, sedangkan pada kategori madaniyyah hanya satu tahap.
\end{abstract}

ABSTRACT: This paper discusses the story in the Al-Qur'an in the madkhal ila Al-Qur'an alKarim by M. Abed al-Jabiri. This study is important to see the concept of the Al-Qur'an story as one of the analytical tools for interpreting the Al-Quran. Besides that, in this interpretation M. Abed al-Jabiri has a big idea about the development of ulumul quran which according to him 
has only been running in place, so that a new analysis is needed to capture the messages that the Qur'an wants to convey. In this book, al-Jabiri's initial steps were to reconstruct the meaning of the Koran, al-Jabri provided a critique of the various definitions constructed by classical scholars such as al-Suyuti, al-Syanqiti, al-Isfahani and so on. . Furthermore, al-Jabiri classified the letters of the Al-Qur'an which speak of stories in the category of makiyyah and madaniyyah. The category of makiyyah is divided into two stages, while in the madaniyyah category there is only one stage.

Kata Kunci : Kisah Al-Qur'an, ulumul qur'an, M. Abed al-Jabiri.

\section{PENDAHULUAN}

Al-Qur'an merupakan kitab yang shalib li kulli zaman wa makan (sesuai dengan waktu dan tempat). Pernyataan ini menunjukkan bahwa Al-Qur'an tidak pernah basi dan selalu ditafsirkan sesuai dengan kebutuhan zaman. Dalam diskursus Al-Qur'an muncul dan berkembang berbagai perspektif, salah satunya dengan pendekatan historis. Dengan menggunakan perspektif historis, Al-Qur'an sangat menarik untuk dikaji. $\mathrm{Hal}$ ini karena faktanya isi kandungan $\mathrm{Al}-$ Qur'an memuat tentang historis, meskipun Al-Qur'an bukan-lah kitab sejarah. ${ }^{1}$

Salah seorang ilmuan dari kalangan insider (baca: Islam) muncul nama Mohamed Abed Al-Jabiri yang menggunakan pende-katan historis dalam mengkaji Al-Qur'an. Pemikiran-pemikiran yang ia kemukakan mendapat respons positif dan sangat dimi-nati di kalangan pengkaji studi Al-Qur'an dan ulumul Qur'an. Melalui buku-bukunya ia memiliki proyek besar "pembaharuan pemikiran Islam" agar Islam kembali kepada masa kejayaan yang pernah diraih. Muncul-nya kitab Madkhal ila Al-Qur'an al-Karim; alJuz Awwal fi al-Ta'rif bi Al-Qur'an yang ia tulis merupakan salah satu upaya mencapai tujuan di atas melalui kajian Al-Qur'an seca-ra komprehensif. Tulisan ini akan menga-nalisis secara metodologis kitab

${ }^{1}$ Wardatun Nadhiroh, 'Fahm Al-Qur'an AlHakim; Tafsir Kronologis Ala Muhammad Abid Al-Jabiri', Jurnal Ilmiah Ilmu Ushuluddin, 15.1 (2017), 13-24 (h. 13). tersebut dan gagasan pokok yang ingin disampaikan oleh Al-Jabiri.

\section{KONTEKS HISTORIS DAN INTE- LEKTUAL AL-JABIRI}

Nama lengkap tokoh ini adalah; Mohammed 'Abed al-Jabiri. Ia dilahirkan di Fejii, Maroko, 27 Desember 1935 dari pasangan Mohammed dan al-Wazinah. Dalam dirinya mengalir darah ulama besar dari pihak ibu dan darah nasionalis dan pejuang kemerdekaan dari pihak ayah. Saat ia dilahirkan, ketika itu Maroko merupakan salah satu negara protektorat penjajah koloni Prancis dan Spanyol. Masa kecil alJabiri cukup menyenangkan dan segala kebutuhan-nya selalu terpenuhi oleh keluarganya. Kelu-arga dari pihak ibu dan bapaknya sangat menyayangi dan memperlakukannya dengan istimewa. Meskipun kedua orang tuanya berscerai sejak ia masih dalam kandungan, akan tetapi ia selalu mendapatkan fasilitas dan kasih sayang yang sukup dari keduanya sejak lahir hingga usia tujuh tahun. ${ }^{2}$

Mesjid Jami' Zinakah merupakan tem-pat al-Jabiri memulai pendidikannya di bawah Asuhan al-Haj Muhammad Faraj sembari menyelesaikan pendidikan formalnya di sebuah sekolah agama. Ia juga pernah merasakan pendidikan di Sekolah Dasar Prancis selama dua tahun. Setamatnya dari sekolah tersebut ia melanjutkan ke cabang sekolah swasta nasionalis (Madrasah Hurrah Wataniyyah),

\footnotetext{
${ }^{2}$ M. Abed Al-Jabiri, Hafriyat fi al-Zakirah min Ba'id (Beirut: Markaz Dirasat al-Wihdah al'Arabiyyah, 1997), h. 26.
} 
yang didirikan oleh al-Haj Muhammad bin Faraj dan tokoh gerakan kemerdekaan yang ada di Ferij hingga tahun 1949. Selanjutnya, jenjang pendidikan al-Takmili ia lalui di tanah kelahirannya, Fejii. Pada masa ini, Al-Jabiri mulai melatih diri dan membiasakan menulis hingga menjadi skillnya di kemudian hari. Ia juga telah membaca, mempelajari, menghafal bukubuku standar untuk pendidikan tradisional , seperti: Mukhtasar Khalil, Alfiyyah Ibn Malik, Qasa'id Umru'u al-Qais dan lain sebagainya.

Pendidikan al-Jabiri berikutnya berlan-jut setelah ia menyelesaikan jenjang al-Takmili, antara tahun 1950-1951, ia melan-jutkan pada tingkat I'dadiyyah di salah satu Madrasab al-Hurrah al-Wataniyyah al-Ma'ra-biyyah yang berafiliasi kepada sekolah swasta nasional yang didirikan oleh gerakan kebang-saan. Pada tahun ini (1951) ini, tepatnya di akhir pendidikannya di Wijdah, ibunya meninggal dunia. Di Wijdah, ia menempuh pendidikannya selama satu tahun, setelah itu ia masuk ke sekolah setingkat menengah atas di al-Dar al-Baida (Casablanca) dan menyelesaikannya tahun 1953. Pendidikan di tempat baru ini menggunakan bahasa Arab sebagai pengantar pertama dan bahasa Prancis sebagai bahasa kedua. Masa pendidikan tingginya, ia tempuh di Universitas Damas-kus, Syria (satu tahun), lalu pindah ke Universitas al-Khamis (V) sampai lulus hingga jenjang doktoral. ${ }^{3} \mathrm{Al}-$ Jabiri meninggal pada tanggal 3 Mei 2010 di Casablanca dalam usia 75 tahun. ${ }^{4}$

Al-Jabiri merupakan ilmuwan yang sangat produktif menghasilkan karya-karya berkualitas. Tulisannya mencakup bahasan

3 Mohamad Yahya, 'Al-Qasas al-Qur'ani Perspektif M. Abed Al-Jabiri' (Universitas Islam Negeri Sunan Kalijaga Yogyakarta, 2010), h. 27.

${ }^{4}$ Hamzah Harun Al-Rasyid, 'Biografi Muhammad Abed Al-Jabiri', http://hamzabharun.blogspot.com/ <http://hamzahharun.blogspot.com/2012/02/biografimuhammad-abid-al-jabiri.html> [accessed 19 February 2020$]$. filsafat, pemikiran Islam, diskursus AlQur'an dan lain sebagainya. Di antara karya-karya beliau yang relevan dengan kajian ini antara lain sebagai berikut:

1. Takwin al-'Aql al-'Arabi (Formasi Nalar Arab). Karya ini merupakan volume pertama dari proyek monumentalnya, kritik nalar Arab. Volume pertama ini diterbitkan pada tahun 1984 oleh Markaz Dirasat alWihdah al-'Arabiyyah. Dilanjutkan dengan Binyah al-'Aql al-'Arabi: Dirasah Tah-liliyyah-Naqdiyyah li Nuzum al-Ma'rifah fi al-Saqafah al'Arabiyyah (Struktur Nalar Arab: Studi Analitis-Kritis atas Sistem Pengetahuan dalam Budaya Arab) yang diterbitkan tahun 1985 oleh alMarkaz al-Saqafi al-'Arabi.

2. Madkhal ila Al-Qur'an al-Karim; alJuz Awwal fi al-Ta'rif bi Al-Qur'an (Pengantar Menuju Al-Qur'an alKarim: Bagian pertama tentang Penaf-siran Al-Qur'an). Karya ini merupakan karya tafsirnya, diterbitkan tahun 2006 oleh Markaz Dirasat al-Wihdah al-'Arabiyyah. Karya ini pada mulanya berupa tulisan-tulisan lepas Al-Jabiri tentang Al-Qur'an di situs internet yang ia kelola. Meskipun demikian, jauh sebelumnya Al-Jabiri memang sudah merancang hal tersebut untuk memfokuskan pada kajian AlQur'an.

3. Fahm Al-Qur'an al-Hakim: al-Tafsir al-Wadih Hasba Tartib al-Nuzul (Wa-wasan Al-Qur'an al-Hakim: Sebuah tafsir yang Jelas dalam Paradigma Kronologi Penurunan). Karya ini berjumlah tiga juz. Juz pertama dan kedua terbit tahun 2008, sedangkan juz ketiga terbit pada tahun 2009.

Selain karya-karya di atas, masih banyak karya Al-Jabiri dalam bentuk artikel dan publikasi dalam jurnal-jurnal ilmiah 
yang dapat dilihat di situs pribadi yang ia kelola, www.aljabriabed.net. ${ }^{5}$

\section{KAJIAN METODOLOGIS KITAB MADKHAL ILA AL-QUR'AN AL- KARIM}

Kitab yang dibahas dalam tulisan ini yaitu, Madkhal ila Al-Qur'an al-Karim; alJuz Awwal fi al-Ta'rif bi Al-Qur'an (Pengantar Menuju Al-Qur'an al-Karim: Bagian pertama tentang Penafsiran AlQur'an). Diterbitkan oleh al-Markaz. Dirasat al-Wibdah al-'Arabiy-yah di Beirut pada tahun 2006. Secara fisik kitab ini cukup tebal, terdiri dari 456 halaman dengan cover berwarna putih, coklat dan hijau. Menurut hemat penulis, kitab ini bukanlah kitab tafsir, melainkan kitab 'ulum al-Tafsir atau 'ulum Al-Qur'an. Untuk memudahkan dalam mengenal dan mengkaji kitab ini, penulis akan menjelaskan dengan poin-poin berikut:

\section{Latar Belakang dan Sistematika Penulisan}

Pada bagian pendahuluan sudah penulis singgung bahwa al-Jabiri meru-pakan ilmuwan yang produktif menulis dan visoner. Ia mempunyai proyek besar pembaharuan pemikiran Islam dengan pemahaman turas (tradisi) yang mapan. Gagasannya yang cemerlang membuatnya sangat disegani di bidang kajian-kajian keIslam-an. Pada bebera-pa karyanya ia mengkritik budaya dan nalar Arab yang menurutnya membu-tuhkan reformasi agar umat Islam umumnya tidak mengalami keterting-galan dalam berbagai aspek kehidupan.

Ketekunannya di bidang ilmuilmu ke-Islam-an terutama ulumul qur'an ia tunjukkan dengan menulis kitab ini yang sudah ia rancang sejak

\footnotetext{
${ }^{5}$ M. Abed Al-Jabiri, 'Muallifat Doktor Mohammed Abed Al-Jabiri' $<$ http://www.aljabriabed.net/> [accessed 20 February 2020$]$.
}

jauh-jauh hari dengan tujuan untuk menjelaskan langkah-langkah dalam kajian Al-Qur'an. Adapun sistematika penulisan kitab ini mengikuti pola penulisan kitab-kitab ulumul qur'an pada umumnya. Untuk memudahkan, di awal kitab ini terdapat daftar isi sebagai gambaran dari keseluruhan kandungan kitab.

Kitab ini terbagi kepada tiga bagian besar. Bagian pertama menjelaskan tentang hal-hal yang

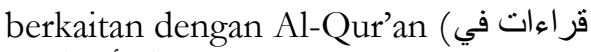
(محيط القرأن الكريم . Terdiri dari lima fasl yang berbicara tentang dakwah muhammadiyah, Nabi Ummiy, wahyu dan penetapan dan hakikat kenabian. Bagian kedua mema-parkan ( مسار (الكون و التكين , terdiri dari lima fasl yang membahas pengertian Al-Qur'an, qira'at, tartib mushafi dan tartib nuzuli. Pada bagian ini Al-Jabiri mengu-pas tentang bagaimana penulisan Al-Qur'an berdasarkan tartib mushafi dan nuzuli, urgensinya pembahasan ini men-jadi landasan AlJabiri untuk menelaah kisah dalam AlQur'an yang dibahas pada bagian selanjutnya. Pada bagian akhir yaitu bagian ketiga dari kitab ini, mengkaji secara mendalam tentang (القصص في (القرأن الكريم . Tema ini juga menjadi pembahasan inti pada makalah ini dan akan penulis paparkan pada poin selanjutnya.

\section{Metode Penulisan}

Kitab Madkhal ila Al-Qur'an alKarim; al-Juz Awwal fi al-Ta'rif bi AlQur'an karya Al-Jabiri ditulis dengan bahasa yang sederhana dan mudah dipahami, meskipun penulis belum bisa memahami secara komprehensif. Kitab ini termasuk ke dalam kitab ulumul qur'an kontemporer yang ditulis dengan gaya pemetaan poinpoin tertentu seca-ra lengkap dan 
detail. Dilengkapi de-ngan mukadimah dan penutup secara keseluruhan tentang isi kitab.

\section{Kelebihan dan Kekurangan}

Menurut hemat penulis, kelebihan kitab ini adalah gaya penulisan yang sis-tematis dan pembahasan yang jelas dan padat. Dari segi isi, pemetaan tentang kisah dalam Al-Qur'an sangat menarik. AlJabiri memetakan kisah Al-Qur'an kepada empat marhalah sehingga pada setiap tahapan mudah untuk dipahami.

Adapun kekurangan kitab ini, menurut hemat penulis tidak terdapat metodologi penafsiran yang spesifik dalam mengungkap kisah-kisah tersebut. Oleh karena itu, sangat terbuka ruang untuk meneliti atau mengkaji kitab ini di masa selanjutnya.

\section{KISAH DALAM AL-QUR'AN PER- SPEKTIF AL-JABIRI}

Sebelum lebih jauh masuk ke pembahasan Kisah dalam Al-Qur'an menu-rut Al-Jabiri, penulis akan terlebih dahulu memaparkan konsep kisah dalam Al-Qur'an secara umum. ${ }^{6}$

Al-Qur'an merupakan kitab budan (petunjuk) bagi manusia. Ajaran-ajarannya disampaikan secara variatif serta dikemas sedemikian rupa. Ada yang berupa informasi, perintah dan larangan, dan ada juga yang dimodifikasi dalam bentuk kisahkisah yang mengandung ibrah, yang dikenal de-ngan "kisah-kisah dalam Al-Qur'an". Kesusastraan kisah dewasa ini telah men-

6 Abd Haris, 'KAJIAN KISAH-KISAH DALAM AL-QUR'AN (Tinjauan Historis Dalam Memahami al-Qur'an)', Al-Ulum Jurnal Pemikiran Dan Penelitian Ke Islaman, 5.1 (2018), 59-71 (p. 70) $<$ https://doi.org/10.31102/alulum.5.1.2018.59$71>$.

${ }^{7}$ Muhammad Chirzin, Al-Qur'an dan Ulumul Qur'an (Yogyakarta: Dana Bhakti Prima Yasa, 1998), h. 118. jadi seni yang khas di antara seni-seni bahasa dan kesusasteraan. Dan kisah yang benar telah membuktikan kondisi ini dalam gaya bahasa Arab secara jelas dan menggam-barkannya dalam bentuk yang paling tinggi. ${ }^{8}$

Dari segi bahasa, kata kisah berasal dari kata bahasa Arab "al-Qashshu" atau "al-Qishshatu" yang berarti cerita." Ia searti dengan "tatabbu'ul atsar" yaitu pengulangan kembali hal masa lalu. Kata al-Qashash adalah bentuk masdar, seperti disebutkan dalam firman Allah "fartadda 'ala atsaribima qashasha" (Lalu keduanya kembali, mengikuti jejak mereka semua) dalam (QS. Al-Kahfi [18]: 64). Sedangkan dari segi istilah, kisah berarti berita-berita mengenai suatu permasalahan dalam masa-masa yang berturut-turut. Se-dangkan Qashshash AlQur'an adalah pem-beritaan Al-Qur'an mengenai hal-ihwal umat yang telah lalu, nubunwat (kenabian) dan peristiwaperistiwa yang terjadi pada zaman nabi.

Kisah-kisah dalam Al-Qur'an terdiri dari tiga macam; Pertama, kisah para Nabi terdahulu. Kisah ini mengandung informasi mengenai dakwah para Nabi kepada kaum-nya, mukjizat-mukjizat yang memperkuat dakwahnya, sikap orangorang yang memu-suhinya, tahapantahapan dakwah dan per-kembangannya serta akibat-akibat yang diterima oleh mereka yang mempercayai dan golongan yang mendustakan. Misalnya kisah nabi Nuh, Ibrahim, Musa, Harun dan Isa.

Kedua, kisah-kisah yang menyangkut pribadi-pribadi dan golongan-golongan ter-tentu dengan segala kejadiannya yang dinukil oleh Allah untuk dijadikan pelajaran bagi umat berikutnya, seperti kisah Maryam, Lukman, Dzulqarnain, Qarun dan Ashabul Kahfi.

\footnotetext{
${ }^{8}$ Manna' Khalil Al-Qattan, Studi Ilmu-ilmu Qur'an (Bogor: Litera AntarNusa, 2012), h. 430.

${ }^{9}$ Ahmad Warson Al-Munawwir, Kamus AlMunawwir (Yogyakarta: UPBIK, PP Krapyak, 2009), h. 127.
} 
Ketiga, kisah-kisah yang menyangkut peristiwa-peristiwa pada masa Rasulullah Saw seperti perjuangan Rasulullah pada perang Badr, perang Uhud, perang Ahzab, dan dengan Abu Lahab.

Bentuk-bentuk kisah yang ada dalam Al-Qur'an tersebut tentunya bukan sebagai dongeng semata, namun lebih dari itu salah satu hikmah kisah tersebut adalah sebagai kekuatan i'jaz (kemukjizatan) serta sebagai bentuk ta'kid (penegasan) terhadap makna yang terkandung di dalam kisah tersebut. ${ }^{10}$

Selanjutnya, disini penulis juga terlebih dahulu akan memaparkan makna dari istilah-istilah pokok dalam pembahasan ini. Hal ini bertujuan untuk menganalisis konsistensi dan melihat bagaimana implikasi dari peng-gunaan istilah-istilah tersebut.

\section{Al-Qur'an}

Definisi Al-Qur'an sangat penting untuk dijelaskan karena $\mathrm{Al}$ Jabiri ingin memberikan pemahaman baru supaya lebih mudah dipahami dan sesuai dengan apa yang dimaksud oleh Al-Qur'an itu sendiri sesuai dengan nama-namanya (self identity). ${ }^{11}$ Dalam kitab ini, al-Jabiri memberikan kritik atas berbagai definisi yang telah dikonstruksi oleh para ulama seperti al-Suyuti, alSyanqiti, al-Isfahani dan lain sebagainya. ${ }^{12}$ Kaitannya dengan AlQur'an, dalam tinjauan etimologis, al-Jabiri mengklasifikan ragam penda-pat ulama menjadi dua, yaitu: Pertama, kata Al-Qur'an adalah ghair mabmuг. (kata yang tidak terdapat

\footnotetext{
${ }^{10}$ Hasbi Ash-Shiddieqy, Ilmu-Ilmu Al-Qur'an (Semarang: Pustaka Rizki Putra, 2009), h. 181.

${ }^{11}$ Muhammad Yasir and Ade Jamaruddin, Studi Al-Qur'an (Pekanbaru: Asa Riau, 2016), h. 9 $<$ https://fush.uin-

suska.ac.id/index.php/2016/11/09/studi-alquran $/>$.

12 Jalaluddin Al-Suyuti, Al-Itqan fi Ulum alQur'an (Beirut: Maktabah al-Asyriyyah, 1987), h. 27.
}

huruf hamzah dan huruf-huruf pemben-tukannya), dengan pengertian bahwa ia bukan berasal dari kata "al-Qira'ab". Kedua, kata AlQur'an adalah mabmuz: Akan tetapi, para ulama berpendapat demikian berbeda pandangan menge-nai sighah-nya.

Al-Jabiri mendefinisikan AlQur'an merujuk pada literatur bahasa yang memaparkan bahwa AlQur'an berasal dari kata; qara'ayaqra'u-qira'atan-wa qur'anan.

Menurutnya, definisi semacam ini selaras dengan penurunan ayat pertama yang berbunyi : "iqra' bi Ism Rabbik" dimana Nabi Muhammad SAW sebagai mukhattab, menjawabnya dengan; "maza aqra'?". pendapat ini ia sandarkan pada beberapa ayat QS. Al-Qiyamah [75]: 16-19.

Sebagaimana mendefinisikan Al-Qur'an secara etimologis, dalam tinjauan terminologis ia juga menggu-nakan cara yang sama. Dalam arti, ia mengacu kepada ayatayat Al-Qur'an yang mengandung hal tersebut, seperti QS. Asy-Syu'ara' [26]: 192-196. Dari beberapa ayat tersebut Al-Jabiri memetakan dua proposisi dalam men-definisikan AlQur'an, yakni proposisi zamaniyyah yang berisifat historis dan proposisi azaliyyah yang bersifat ahistoris.

Berdasarkan ayat-ayat di atas, Al-Jabiri menjelaskan bahwa yang dimak-sud dengan Al-Qur'an adalah wahyu Allah yang dibawa oleh Jibril kepada Muhammad dengan menggunakan bahasa Arab, dan termasuk dalam jenis wahyu yang terdapat dalam kitab-kitab para

\footnotetext{
13 Afriadi Putra, 'Isu Gender dalam AlQur'an: Studi Penafsiran Kontekstual Abdullah Saeed Terhadap Ayat-ayat Warisan', Kafa 'ab: Journal of Gender Studies, 7.2 (2017), 209 (h. 212) <https://doi.org/10.15548/jk.v7i2.176>.
} 
Rasul terdahulu. Untuk itu, terdapat tiga aspek pemahaman yang dapat diambil dari definisi tersebut, yakni; Pertama, Al-Qur'an bukanlah hal yang sama sekali baru, melainkan lanjutan seruan Tuhan kepada manusia. Kedua, proses penerimaan wahyu tersebut merupakan pengalaman ruhani yang tidak dialami oleh sembarangan manusia. Ketiga, AlQur'an adalah risalah, yang menjadikan pembawanya sebagai bagian dari pemberi peringatan (munzir) dan penjelas (mubin) bagi manusia tentang persoalan yang haq dan bathil. ${ }^{14}$ Definisi itulah yang menurutnya bersifat objektif, karena ia terbangun dari ungkapan AlQur'an sendiri dan terhindar dari nuansa ideologis.

\section{Kisah (al-Qasas Al-Qur'ani) dan Sistematika Tartib Nuzuli}

Secara umum, menurut etimologi qasas adalah bentuk jamak dari kata qass yang berarti mengikuti jejak. Ibnu 'Asyur memberikan pengertian yang berbeda, bentuk plural dari qissah adalah qisas (dengan huruf kaf yang di-kasrab). Sedangkan qasas (dengan qaf yang di-fathab) adalah term yang digunakan untuk warta yang dikisah-kan. Secara terminologi, al-Qasas Al-Qur'ani dapat didefinisikan dengan pemberitaan Al-Qur'an tentang kea-daan umat masa lalu, Nabi-nabi terdahulu, dan berbagai peristiwa yang telah terjadi. Artinya, dengan definisi tersebut kejadian apapun di masa lampau yang telah diberitakan AlQur'an termasuk dalam kategori kisah.

\footnotetext{
${ }^{14}$ Mohammed Abed Al-Jabiri, 'Madkhal ila al-Qur'an al-Karim' (Markaz Dirasat al-Wihdah al'Arabiyyah, 2006), h. 24.
}

Sementara itu, meskipun AlJabiri tidak menyebutkan secara spesifik definisi kisah, akan tetapi jika dilihat dari konsistensinya dalam mengungkapkan sebuah istilah, maka akan dikembalikan kepada objek kajian itu sendiri, yaitu AlQur'an. Sehingga untuk memahami kisah itu, Al-Jabiri mengacu kepada istilah dalam Al-Qur'an dengan pengertian, "mengikuti jejak" dan "cerita yang berurutan". Pada pengertian terminologi bisa disimpulkan dari penuturannya yang mengatakan bahwa Al-Qur'an meng-gunakan kisah untuk tujuan dakwah keagamaan, bukan semata dari sisi pengisahan itu sendiri. Menurut Al-Jabiri, Al-Qur'an bukanlah kitab yang hanya berisi cerita dan bukan pula kitab sejarah, tetapi ia adalah kitab dakwah keagamaan (da'wah diniyyah).

Alasan Al-Jabiri mengupas persoalan kisah Al-Qur'an dalam karya pengantar tafsirnya adalah; ${ }^{15}$ Pertama, di satu sisi kisah Al-Qur'an merupakan jendela luas yang memungkinkan pembaca untuk menguasai berbagai persoalan penting persoalan da'wab mubammadiyah, di sisi lain merupakan seruan yang menjadikan Al-Qur'an sebagai arena untuk mengungkap perdebatan abadi dalam menghadapi para penentangnya, di mana mereka dituntut untuk mengambil inti pelajaran dari pengalaman tersebut. ${ }^{16}$ Kedua, kisah-kisah Al-Qur'an merupakan pembentuk dasar diantara

${ }^{15}$ Faizin Faizin, 'Kisah Al-Qur'an dalam Tinjauan Sains (Studi atas Serial Tafsir Ilmi Kementerian Agama RI)', AL QUDS : Jurnal Studi Alquran dan Hadis, 4.1 (2020), 77-96 (p. 85) $<$ https://doi.org/10.29240/alquds.v4i1.1106>.

${ }^{16}$ Mohammed Abed Al-Jabiri, 'Madkhal ila al-Qur'an al-Karim' (Markaz Dirasat al-Wihdah al'Arabiyyah, 2006), h. 257. 
berbagai komponen pembentukan perjalanan formatifnya. Karena itu, tujuan dari kajian atas kisah AlQur'an bagi Al-Jabiri adalah mengungkap sinergitas antara da'wah mubammadiyah dengan proses perwujudan dan formasi Al-Qur'an .

Sinergisitas tersebut nampak lebih jelas gambarannya melalui urutan tahapan kisah Al-Qur'an dengan menggunakan sistematika tartib nusuli. Dari sinilah, ia tetap konsisten dalam menggunakan sistematika tersebut sebagai format kajian kisah Al-Qur'an. Begitupun dengan pola ideografi (pola gagasan), dimana pola ini sangat berhubungan dengan dua alasan di atas.

Dalam memahami kisah AlQur'an, Al-Jabiri menggunakan sistematika dan pola yang sama dalam kajian Al-Qur'an secara umum, yakni tartib nuquli dengan pola ideografi. Pada kitab ini (Madkhal ila Al-Qur'an al-Karim; alJuz Awwal fi al-Ta'rif bi Al-Qur'an) Al-Jabiri mengungkapkan bahwa:

(...sesungguhnya kisah AlQur'an serupa dengan cermin yang di dalamnya terlihat da'wah muham-madiyah, baik di masa lalu, saat itu, maupun masa yang akan datang, dimana ia juga dapat dikatakan sebagai al-tarikh al-muqaddas, yakni sejarah para Nabi dan Rasul. Dalam pada itu, berkali-kali saya tegaskan pada fasal-fasal terda-hulu tentang pentingnya mengungkap sinergi antara da'wah mubammadiyah dan proses perwu-judan dan formasi AlQur'an. Sesungguhnya sinergi ini akan nampak lebih jelas dengan melacak dinamika tahapan kisah Al-Qur'an, dengan menggunakan sistematika kronologi pewah-yuan).

Adapun tartib nuzuli yang digunakan Al-Jabiri dalam mengkaji kisah Al-Qur'an pada karya pengantarnya adalah versi al-Azhar (Mesir). ${ }^{17}$ Kemudian Al-Jabiri mengklasifikasi surat-surat AlQur'an yang berbicara tentang kisah dalam kategori makiyyah dan madaniyyah. Kategori makiyyah, dibagi dalam dua tahap, sedangkan pada kategori madaniyyah hanya satu tahap:

\section{Makiyyah Tahap Pertama}

Tahap pertama ini dimulai dari QS. Al-Fajr sampai QS. Al-Qamar. Pada tahap ini persoalan yang dimunculkan dalam berbagai kisah pada rangkaian surat-surat tersebut adalah ancaman dengan tempat kembalinya para kaum yang telah mendustakan Nabi mereka, dan yang menjadi mukhattab dalam ayatayat ini adalah penentang da'wah mubam-madiyah, baik secara terangterangan maupun sembunyisembunyi. Tujuan mendasar bagian ini adalah untuk menakut-nakuti dan memperingatkan mereka dengan apa yang sudah menimpa kaum sebelum mereka. Secara umum, bagian ini menampilkan kisah-kisah "para penduduk desa" bersama para Nabinya, dimana para Nabi tersebut tidak disebutkan di dalam kitab Taurat maupun Injil. Karena para Nabi tersebut hidupnya lebih dahulu dari Nabi-nya Bani Israil.

\section{Makiyyah Tahap Kedua}

Tahapan ini bermula dari QS. Sad hingga QS. Al-'Ankabut. Pada tahap ini, persoalan yang dimunculkan adalah pujian atas para Nabi dan menyindir serta

${ }^{17}$ Taufik Adnan Amal, Rekonstruksi Sejarah Al-Qur'an (Jakarta: Alvabet, 2013), h. 103-6. 
menampakkan apa yang telah Allah tentukan pada diri setiap Nabi tentang tanda-tanda yang jelas. Selain itu, hal tersebut juga bertujuan untuk melemahkan manusia dalam konteks mendatangkan padanannya. Tujuan kisah-kisah yang tercakup dalam tahapan ini adalah menetapkan kebenaran kenabian dan risalah para Nabi. Dalam tahapan ini, secara umum para Nabi yang disebutkan adalah Nabi-nabi Bani Israil.

\section{Madaniyyah}

Tahapan ini dimulai dari tahun pertama Nabi hijrah ke Madinah hingga wafatnya. Pada tahap ini, persoalan yang dimunculkan adalah; perbedaan perdebatan Nabi dengan kaum Yahudi dan Nasrani seputar konsep ke-Tuhanan, tuduhan kepada mereka atas pengingkaran nikmat yang telah Allah berikan pada mereka serta kelebihan mereka yang telah Allah khususkan kepada mereka, dan memperingatkan kedurhakaan serta penyimpangan mereka dari agama Ibrahim yang menjadi nenek moyang Nabi-nabi mereka. Agama Ibrahim ini adalah agama yang lurus, dimana dengan kedatangan risalah mubammadiyah ditujukan untuk mengem-balikan pada bentuk yang asli. Dari tema-tema tersebut, kisah Al-Qur'an yang terurai adakalanya diturunkan dengan bentuk secara lengkap, bersifat penjelasan, atau juga adakalanya yang mengulang kisah-kisah yang terdapat dalam jajaran suratsurat makiyyah, dimana keseluruhannya erat kaitannya dengan kondisi yang dihadapi Nabi pada saat itu (asbab al-nuzul).

\section{KESIMPULAN}

Mohammed 'Abed al-Jabiri merupakan seorang cendekiawan muslim yang progresif dan produktif. Pemikiranpemikirannya sudah banyak mewarnai kajian keislaman. Pandangannya terhadap studi Al-Qur'an dan Ulumul Qur'an memberikan perspektif baru agar kajian ulumul qur'an tidak stagnan. Melalui karyanya, Madkhal ila Al-Qur'an al-Karim; al-Juz Awwal fi al-Ta'rif bi Al-Qur'an (Pengantar Menuju Al-Qur'an al-Karim, ia mengkritisi definisi-definisi Al-Qur'an yang telah dikemukakan oleh para ulama klasik. Menurutnya, untuk mendefinisikan Al-Qur'an harus melihat apa yang terkandung oleh Al-Qur'an itu sendiri atau disebut juga dengan self identity.

Menurut al-Jabiri definisi Al-Qur'an adalah wahyu Allah yang dibawa oleh malaikat Jibril kepada Muhammad dengan menggunakan bahasa Arab, dan termasuk dalam jenis wahyu yang terdapat dalam kitab-kitab para Rasul terdahulu. Sedangkan kisah menurut Al-Jabiri mengacu kepada istilah dalam Al-Qur'an dengan pengertian, "mengikuti jejak" dan "cerita yang berurutan". Al-Jabiri mengklasifikasi surat-surat Al-Qur'an yang memaparkan tentang kisah dalam kategori makiyyah dan madaniyyah. Kategori makiyyah, dibagi dalam dua tahap, sedangkan pada kategori madaniyyah hanya satu tahap.[]

\section{DAFTAR PUSTAKA}

Al-Jabiri, M. Abed, Hafriyat fi al-Zakirah min Ba'id (Beirut: Markaz Dirasat al-Wihdah al-'Arabiyyah, 1997)

_, 'Muallifat Doktor Mohammed Abed Al-Jabiri' $<$ http://www.aljabriabed.net/> [accessed 20 February 2020]

Al-Jabiri, Mohammed Abed, 'Madkhal ila al-Qur'an al-Karim' (Markaz Dirasat al-Wihdah al-'Arabiyyah, 2006) 
Al-Munawwir, Ahmad Warson, Kamus AlMunawwir (Yogyakarta: UPBIK, PP Krapyak, 2009)

Al-Qattan, Manna' Khalil, Studi Ilmu-ilmu Qur'an (Bogor: Litera AntarNusa, 2012)

Al-Rasyid, Hamzah Harun, 'Biografi Muhammad Abed Al-Jabiri', http:/ / hamzah-barun.blogspot.com/ $<$ http://hamzahharun.blogspot.com/2012/02/bio grafi-muhammad-abid-aljabiri.html> [accessed 19 February 2020]

Al-Suyuti, Jalaluddin, Al-Itqan fi Ulum alQur'an (Beirut: Maktabah alAsyriyyah, 1987)

Amal, Taufik Adnan, Rekonstruksi Sejarah Al-Qur'an (Jakarta: Alvabet, 2013)

Ash-Shiddieqy, Hasbi, Ilmu-Imu Al-Qur'an (Semarang: Pustaka Rizki Putra, 2009)

Chirzin, Muhammad, Al-Qur'an Dan Ulumul Qur'an (Yogyakarta: Dana Bhakti Prima Yasa, 1998)

Faizin, Faizin, 'Kisah Al-Qur'an dalam Tinjauan Sains (Studi atas Serial Tafsir Ilmi Kementerian Agama RI)', AL QUDS: Jumal Studi Alquran dan Hadis, 4.1 (2020), $77-$ 96

$<$ https://doi.org/10.29240/alquds .v4i1.1106>

Haris, Abd, 'KAJIAN KISAH-KISAH DALAM AL-QUR'AN (Tinjauan Historis Dalam Memahami alQur'an)', Al-Ulum Jurnal Pemikiran Dan Penelitian Ke Islaman, 5.1 (2018), 59-71 $<$ https://doi.org/10.31102/alulu m.5.1.2018.59-71>

Nadhiroh, Wardatun, 'FAHM ALQUR'AN AL-HAKIM; TAFSIR KRONOLOGIS ALA MUHAMMAD ABID ALJABIRI', Jurnal Ilmiah Ilmu Ushuluddin, 15.1 (2017), 13-24
Putra, Afriadi, 'Isu Gender dalam AlQur'an: Studi Penafsirsan Kontekstual Abdullah Saeed Terhadap Ayat-ayat Warisan', Kafa ab: Journal of Gender Studies, 7.2 (2017), 209 $<$ https://doi.org/10.15548/jk.v7i $2.176>$

Yahya, Mohamad, 'Al-Qasas al-Qur'ani Perspektif M. Abed Al-Jabiri' (Universitas Islam Negeri Sunan Kalijaga Yogyakarta, 2010) $<$ http://digilib.uinsuka.ac.id/4345/1/BAB\%20I,V.p df $>$

Yasir, Muhammad, and Ade Jamaruddin, Studi Al-Qur'an (Pekanbaru: Asa Riau, 2016) <https://fush.uinsuska.ac.id/index.php/2016/11/0 9/studi-al-quran/> 